OPEN ACCESS

Citation: Fernández M., Bogarín D., Pupulin F. (2021)Anew Muscarella(Orchidaceae: Pleurothallidinae) from Tapantí National Park, Costa Rica. Webbia. Journal of Plant Taxonomy and Geography 76(1): 65-70. doi: 10.36253/jopt10029

Received: November 17, 2020

Accepted: January 3, 2021

Published: April 27, 2021

Copyright:@2021 FernándezM., Bogarín D., Pupulin F. This is an open access, peer-reviewed article published by Firenze University Press (http://www. fupress.com/webbia) and distributed under the terms of the Creative Commons Attribution License, which permits unrestricted use, distribution, and reproduction in any medium, provided the original author and source are credited.

Data Availability Statement: All relevant data are within the paper and its Supporting Information files.

Competing Interests: The Author(s) declare(s) no conflict of interest.

Funding. This paper is part of the project "Ecología y Biología de las Orquídeas Epífitas y sus Micorrizas en el Parque Nacional Tapantí, Costa Rica", under number 814-B6-139, supported by the Vice-Presidency of Research, University of Costa Rica.

Editor: Riccardo M. Baldini

ORCID

DB: 0000-0002-8408-8841

\section{A new Muscarella (Orchidaceae: Pleurothallidinae) from Tapantí National Park, Costa Rica}

\author{
Melania Fernández ${ }^{1,2,3, *}$, Diego Bogarín ${ }^{1,3}$, Franco Pupulin ${ }^{1,4,5}$ \\ ${ }^{1}$ Lankester Botanical Garden, University of Costa Rica, P.O. Box 302-7050 Cartago, Cos- \\ ta Rica \\ ${ }^{2}$ Department of Plant and Soil Science, Texas Tech University, Lubbock, TX 79409, USA \\ ${ }^{3}$ Herbarium UCH, Autonomous University of Chiriquí, Chiriquí, Panama \\ ${ }^{4}$ Harvard University Herbaria, Cambridge, Massachusetts, U.S.A. \\ ${ }^{5}$ The Marie Selby Botanical Gardens, Sarasota, Florida, U.S.A. \\ *Corresponding author. E-mail: melania.fernandez@ucr.ac.cr
}

\begin{abstract}
A new species of Muscarella from Costa Rica, is described and illustrated. Muscarella tapantiensis most resembles $M$. coeloglossa but differs in the longer pedicels (3-5 vs. 1-2 mm), the shorter (2.5-2.8 vs. $3.75 \mathrm{~mm}$ ), connate (vs. free) lateral sepals, and the lip with triangular (vs. broadly rounded) lower lateral lobes. Muscarella xanthella also resembles $M$. tapantiensis; however, it differs in the successively flowered raceme with alternate pedicels, the deeply fimbriate petals and the thick, rounded lip with densely verrucose lateral lobes. We provide illustrations, etymology, notes on ecology, pictures of the plants and habitat, and a distribution map of the new species. We discuss the inclusion of this species in the genus Muscarella.
\end{abstract}

Keywords: floristics, Muscarella coeloglossa, Muscarella xanthella, Neotropics, orchid taxonomy, Specklinia.

\section{INTRODUCTION}

A fundamental principle of any study aimed at understanding the specific relationships among different organisms is to identify them correctly. This simple rule becomes critical and unpractical when the research is carried out in a tropical, biologically-rich region (Higgins and Ruokolainen 2004). Biologists esteem that, in the tropics, only about $86 \%$ of life diversity has been apprehended by science, and the degree of the average knowledge may vary among living groups (Mora et al. 2011).

With over 50,000 ha, Tapantí-Macizo de la Muerte National Park (TNP) is one of the largest protected areas in Costa Rica (Sánchez 2002; Bernard et al. 2009) and one of the species-rich spots for orchids in the country (Pupulin 2003; Pupulin and Bogarín 2012; Crain and Fernández 2020). Because of this high diversity and the ease to reach the park within less than two hours from the capital city of San José, ongoing floristic, ecological and bio- 
geographical projects have been carried out by Lankester Botanical Garden and scientific partners for almost two decades (Pupulin 2001; 2003, Pupulin et al. 2009; Pupulin and Bogarín 2012). In 2015, a long-term research project led by Dr. Jyotsna Sharma from Texas Tech University was initiated to understand if mycorrhizal fungi distribution and specificity influence the distribution of epiphytic orchid species in a community. The massive numbers of co-occurring species there (Figure 1) offer a unique opportunity to test the limits of the species co-existence hypothesis. As part of required taxonomic identification of the epiphytic orchid species subjected to fungal analyses in the study site, a species of Muscarella Luer proved impossible to match with any previously described taxon.

Muscarella is a Neotropical genus of the Pleurothallidinae with around 50 species ranging from Mexico to Brazil and the Antilles (Luer 2006; Pessoa et al. 2014). The genus is distinguished by the cespitose plants with loose racemes, flowers with long-tailed sepals and fringed, fimbriate or denticulate petals, and a thick, fleshy lip that is somehow ciliate (Luer 2006). Most species bear longitudinal calli, and the column-foot is variously concave (Luer 2006). The species of Muscarella were initially treated under Pleurothallis R.Br. and later into a broad concept of Specklinia Lindl. (Pridgeon et al. 2001). Lindley (1830) described Specklinia to include minute, herbaceous plants with flowers of gibbose sepals, free petals and a labellum a third length of the sepals, and membranaceous, winged columns. However, Garay (1974) transferred it to the subgeneric level under Pleurothallis. Then, Luer (1986) built ten sections within Pleurothallis to group species with similar floral features, including a section of minute flowers with thick, fringed or verrucose, lobed lips, which he named Pleurothallis section Muscariae Luer (1986). Later, Pridgeon et al. (2001) proposed a broad concept of Specklinia, sister to the Platystele-Scaphosepalum clade, for small plants with an abbreviated stem with an annulus, flowers with sepals connate to different degrees, a lip hinged to the column foot, and a column provided with a toothed apex and ventral anther and stigma. They based their findings on initial molecular phylogenies of the subtribe. The concept included species of Pleurothallis sections Hymenodanthae Barbosa Rodrigues (1882), Muscariae Luer, and Tribuloides Luer (1986) and species from Acostaea Schltr. (Schlechter 1923), Empusella Luer (Luer 2004) and Pseudoctomeria Kraenzl. (Kraenzlin 1925).

Finally, Luer (2006) considered the new circumscription of Specklinia as a polyphyletic aggregation of many taxa; thus, he proposed the transfer of section Muscariae (Luer 1986) to genus Muscarella. The genus is a monophyletic and morphologically discernible group from the rest of Specklinia, and it is supported by the most recent molecular phylogenetic studies in the Pleurothallidinae (Karremans et al. 2015; Pérez-Escobar et al. 2017)

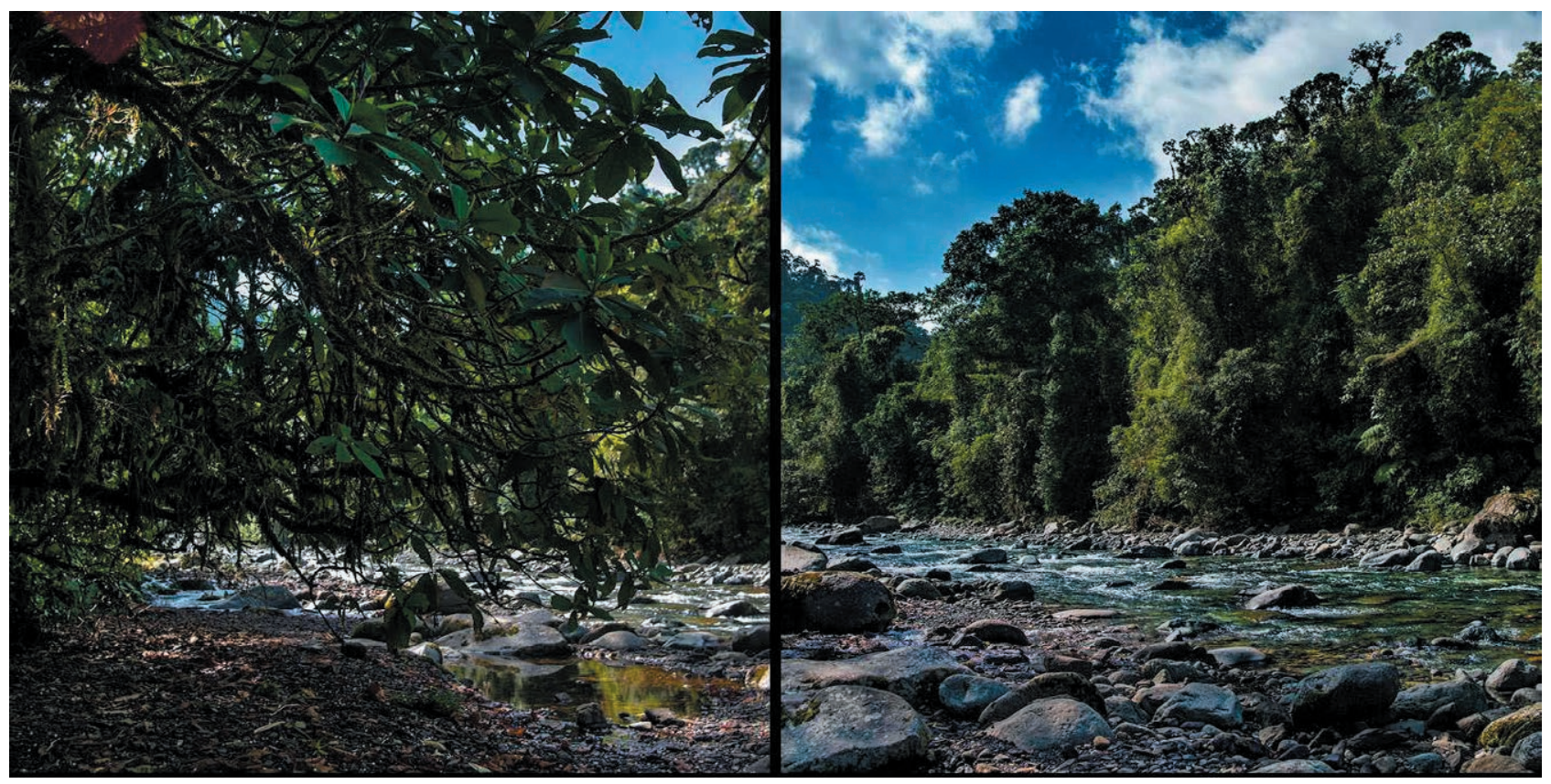

Figure 1. Landscape at Tapantí National Park, along Rio Grande de Orosi, Cartago, Costa Rica, the type locality of M. tapantiensis. Photographs by F. Pupulin. 
Muscarella comprises 11 species in Costa Rica, including the species proposed here as new (Luer 2006; Ossenbach et al. 2007). We describe it hereafter.

\section{MATERIALS AND METHODS}

We collected living specimens at TNP, Cartago, Costa Rica, and cultivated them in the collections at Lankester Botanical Garden (JBL), University of Costa Rica. Living plants were documented with sketches using a Leica ${ }^{\circ}$ MZ9.5 stereo-microscope with a drawing tube. The sketches were digitalized, and the images were used for diagramming a draft composite template in Adobe Photoshop ${ }^{\circ}$ CC. Photographs were taken with a Nikon D7100, Nikon Bellows PB-6 extension, and a Nikon AF-D $50 \mathrm{~mm}$ f/1.8 lens. Descriptions were prepared from both living specimens and herbarium material deposited at JBL. Locality data were obtained with a Garmin eTrex Vista GPS and supporting maps and recorded along with phenology observations in a computerized database at JBL. Ecological zones follow the Holdridge Life Zone System (Holdridge 1967, Holdridge 1987). Distribution maps were made using the geographic information system software ArcView GIS 3.3 (ESRI, California, USA). Specimens were preserved in formaldehyde: acetic acid: ethanol [FAA (53\% ethanol, 37\% water, $5 \%$ formaldehyde, and $5 \%$ glycerol)].

\section{RESULTS}

Muscarella tapantiensis Mel.Fernández \& Bogarín, sp. nov. (Figure 2.).

Type: COSTA RICA, Cartago: Paraíso, Orosi, Tapantí, Parque Nacional Tapantí, bajando por el sendero Oropéndola, epífitas a lo largo del borde del río Grande de Orosi, $9^{\circ} 44^{\prime} 10.15^{\prime \prime} \mathrm{N} 83^{\circ} 46^{\prime} 54.80^{\prime \prime} \mathrm{W}, 1330 \mathrm{~m}$, bosque pluvial premontano, 25 setiembre 2015, M. Fernández 1080, L. Oses and A. Orellana (holotype JBL-spirit, J0159).

\section{Diagnosis}

Muscarella tapantiensis most resembles $M$. coeloglos$s a$ (Luer and Hirtz) Luer but differs from it by the longer pedicels (3-5 $\mathrm{mm}$ in $M$. tapantiensis vs. $1-2 \mathrm{~mm}$ ), the shorter (2.5-2.8 vs. $3.75 \mathrm{~mm}$ ), connate (vs. free) lateral sepals, and the lip with triangular (vs. broadly rounded) lower lateral lobes.

\section{Description}

Plant epiphytic, caespitose, erect or subpendent, very small, up to $1.8 \mathrm{~cm}$ tall. Roots slender, flexuous, $0.5 \mathrm{~mm}$

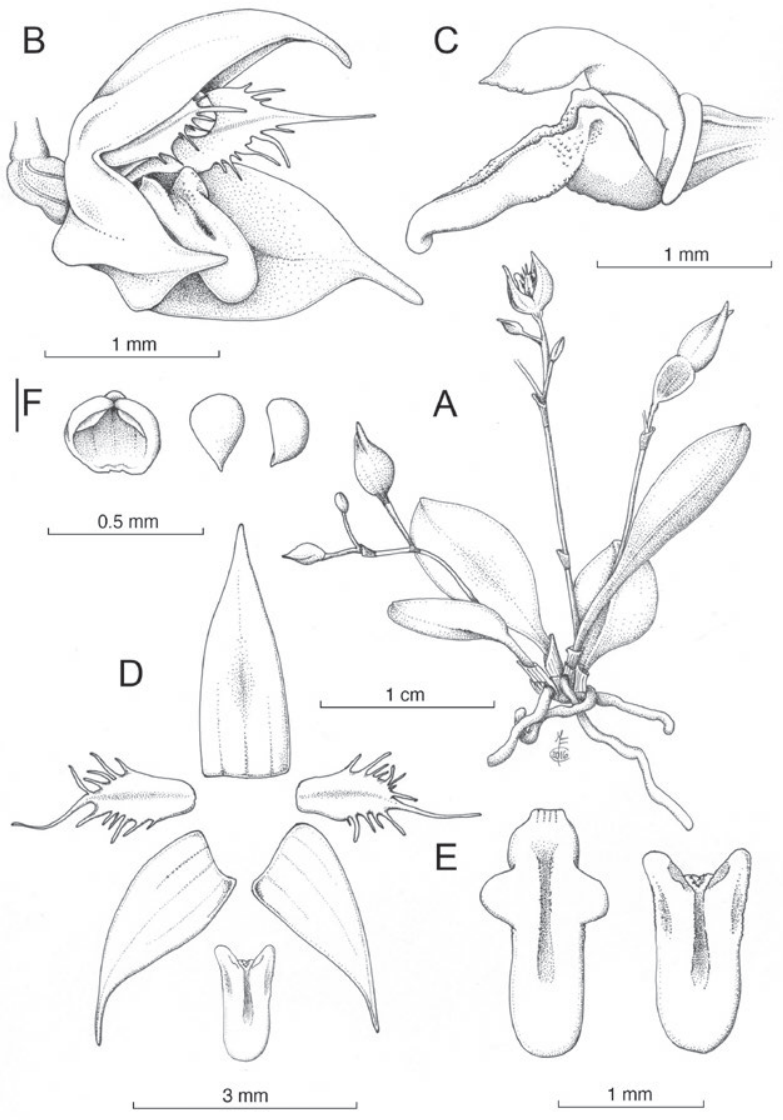

Figure 2. Illustration of Muscarella tapantiensis: A. Habit. B. Flower. C. Column and lip, lateral view. D. Dissected perianth. E. Lip, flattened, and natural position. F. Anther cap and pollinia. Drawn by M. Fernández based on M. Fernández 1080 (holotype).

in diameter. Ramicauls slender, erect, 1.8-4.0 mm long, enclosed by 2 thin, tubular sheaths becoming papyraceous with age. Leaves erect, oblong-elliptic, subacute to obtuse, thick, coriaceous, conduplicate, abaxially cuneate, $0.5-1.3 \times 0.3-0.5 \mathrm{~cm}$, the base narrowing into a petiole 3-5 $\mathrm{mm}$ long. Inflorescence an erect, loose, flexuous, successively flowered raceme producing up to 6 flowers, to $3.5 \mathrm{~cm}$ long, as long as or exceeding the leaves, developed laterally from the ramicaul, peduncle filiform, to $1.7 \mathrm{~cm}$ long, rachis to $2.3 \mathrm{~cm}$ long, floral bracts tubular, acute, to $0.5 \mathrm{~mm}$. Pedicel slender, persistent, to $3-5 \mathrm{~mm}$ long. Ovary terete, widened apically, $0.5 \mathrm{~mm}$ long. Flowers inconspicuous, less than $3 \mathrm{~mm}$ in diameter, sepals and petals translucent yellow-greenish to pinkish, hyaline, the petals with a longitudinal light pink midvein, the yellow lip turning to light green apically, basally stained with purple-red. Dorsal sepal elliptic, acute to acuminate, conduplicate, concave, entire, carinate beneath, briefly connate to the lateral sepals, $2.2-2.5 \times$ 
$0.8-1.0 \mathrm{~cm}$. Lateral sepals ovate, slightly acuminate-subfalcate, concave, entire, carinate beneath, briefly connate at the base, $2.5-2.8 \times 1.0-1.2 \mathrm{~mm}$. Petals elliptic-ovate, fimbriate, aristate, $1.7-2.0 \times 0.6-0.8 \mathrm{~mm}$. Lip oblong, rounded, 3 -lobed, $1.5 \times 1.0 \mathrm{~mm}$ when spread, verrucose and papillose mostly at base, the lateral lobes triangular, acute, minutely erose, erect in natural position, shorter than the midlobe, the midlobe $0.5 \mathrm{~mm}$ wide, rounded, with a longitudinal sulcate callus with two paralell light keels, the apex slightly revolute, hinged to the column foot. Column greenish, terete, widened apically, with two small wings, arcuate, footed, the foot apex concave with two verrucose, lateral thickenings, $1.2-1.3 \times 0.4$ $\mathrm{mm}$. Anther and rostellum subapical, the stigma ventral. Pollinarium with two pyriform pollinia, hooked towards the base, $0.2 \mathrm{~mm}$, lacking accessory structures. Capsule globose, 6-ridged, ridges prominent, green, purple between ridges, $3.5-4.0 \times 3.0 \mathrm{~mm}$. (Figure 2).

\section{Etymology}

After Tapantí National Park, the place where plants of this species were first collected.

\section{Distribution and habitat}

Only known from Costa Rica, growing on mossy twigs, mostly of Saurauia montana (Actinidiaceae), in open areas along or close to riparian premontane wet

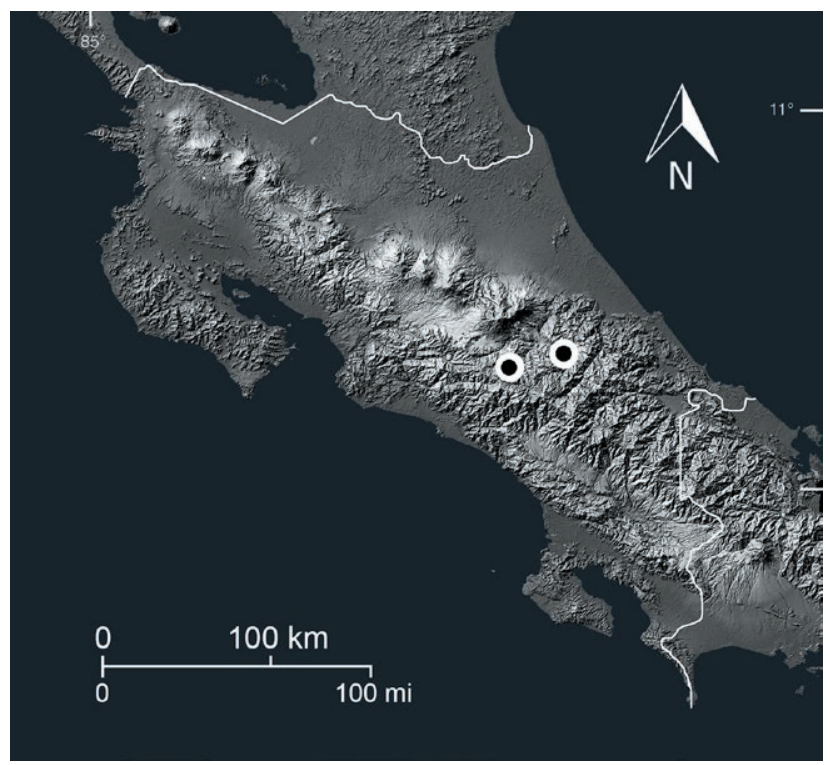

Figure 3. Distribution of Muscarella tapantiensis in Costa Rica (Central America), based on M. Fernández 1080 (holotype), D. Bogarín 9362 \& A. Karremans 4934 (paratypes). Only two marks are shown since the holotype and one paratype were collected in the same area. and rain forests of the Caribbean watershed of the Talamanca mountain range (Figure 3 ).

\section{Flowering time}

Plants were seen in flower in the wild from October to April. At TNP, a flowering peak occurs between November and January.

\section{Additional specimens examined (paratypes)}

COSTA RICA. Cartago: Paraíso, Orosi, Tapantí, Parque Nacional Tapantí, Sendero Oropéndola, orillas del Río Grande de Orosi, 944’37.86”N 8347’04.28”W, 1296 m, epífitas en árbol de Saurauia sp. (Actinidiaceae) a orillas del río, bosque pluvial premontano, 30 octubre 2011, D. Bogarín 9362 and M. Bonilla (JBL-spirit, D4865) (Figure 4). Cartago: Turrialba, Tayutic, Platanillo, siguiendo el camino paralelo al río Platanillo, que va hacia el origen de este, unos $3.5 \mathrm{~km}$ del centro de Platanillo, sobre árboles solitarios en potreros, 947’52.90”N 83³3'44.51"W, 1049 m, 4 febrero 2012, A. Karremans 4934 (JBL-spirit, D5464).

\section{DISCUSSION}

The new species is recognized by the small, less than $3 \mathrm{~mm}$ in diameter, translucent yellow-greenish to pinkish flowers with concave sepals, fimbriate and aristate petals, and a lip with two short lateral lobes, characters that agree with the concept of Muscarella. The new species most resembles the Ecuadorian Muscarella coeloglossa (Luer \& Hirtz) Luer, but differs from it by the longer pedicels $(3-5 \mathrm{~mm}$ in $M$. tapantiensis vs. 1-2 $\mathrm{mm})$, the shorter (2.5-2.8 vs. $3.75 \mathrm{~mm})$, connate (vs. free), apically acuminate (vs. rounded) lateral sepals, and the lip with triangular (vs. broadly rounded) lower lateral lobes. The Ecuadorian Muscarella xanthella (Luer) Luer also resembles M. tapantiensis, mostly because of the more or less elliptic leaves and the small pinkish flowers with concave, translucid sepals. Nevertheless, Muscarella xanthella produces a fasciculouslike inflorescence with pedicels congested at the apex of the peduncle, different from the successively flowered raceme with alternate pedicels of $M$. tapantiensis. When looking closer to the flower, the lacerate petals of Muscarella xanthella differ from the deeply fimbriate ones of $M$. tapantiensis, and the lip is thick, rounded with densely verrucose lateral lobes. In contrast, Muscarella tapantiensis bears thinner, triangular lobes at the base and is papillose mostly at the base. 


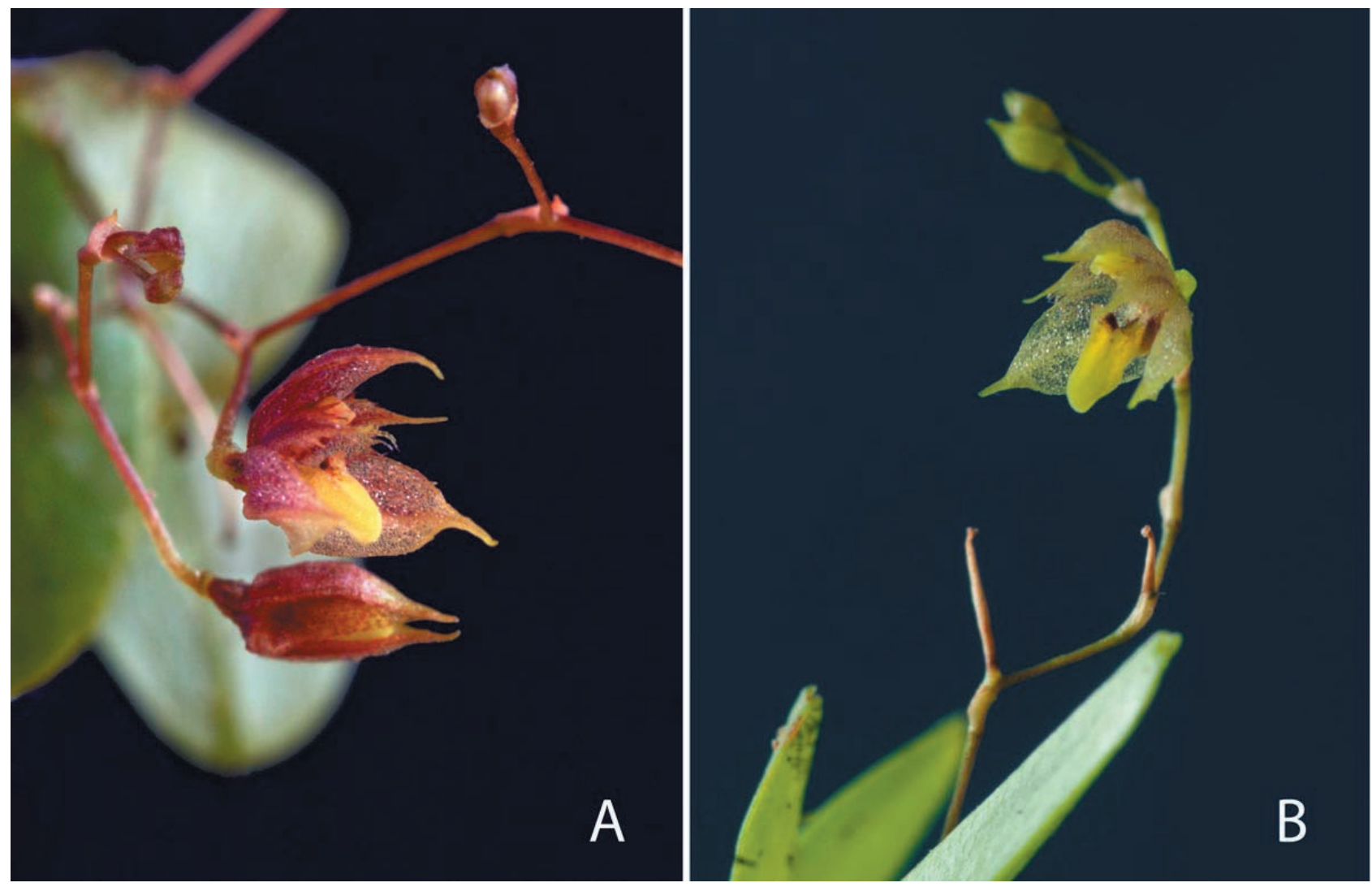

Figure 4. Flowers of Muscarella tapantiensis from Tapantí National Park showing two variations of sepal color: A. Variation with reddish sepals, from the holotype (M. Fernández 1080). B. Variation with yellow sepals, based on D. Bogarín 9362.

\section{ACKNOWLEDGMENTS}

To Dr. Jyotsna Sharma, for her support during the Ph.D. studies of the first author and initial comments on this manuscript. To Adam Karremans for previous comments on the phylogenetic position of Muscarella, and to Lizbeth Oses and Andrea Morales for field support. Meryll Arias, Fabricio Carbonell, Mahyar Shirazinia, Lisandro Zúñiga, and all the staff at TNP for their constant help with logistics and permits. Thanks to the National System of Conservation Areas (SINAC) for the collecting permits.

\section{REFERENCES}

Barbosa Rodrigues J. 1882. Genera et Species Orchidearum Novarum quas collegit, descripsit et iconibus illustravit. II: 9-10. Sebastianopolis: Imprimerie de C. \& H. Fleiuss.

Bernard F, de Groot RS, Campos JJ. 2009. Valuation of tropical forest services and mechanisms to finance their conservation and sustainable use: A case study of Tapantí National Park, Costa Rica. For Policy Econ, 11, 174-183. URL:https://www.sciencedirect. com/science/article/abs/pii/S1389934109000264

Crain BJ, Fernández M. 2020. Biogeographical analyses to facilitate targeted conservation of orchid diversity hotspots in Costa Rica. Diversity and Distribution. 26: 853-866. URL: https://onlinelibrary.wiley.com/ doi/full/10.1111/ddi.13062

Garay LA. 1974. Acostaea y los géneros del complejo Pleurothallis. Orquideología. 9(2): 121-123.

Higgins MA, Ruokolainen, K. 2004. Rapid tropical forest inventory: a comparison of techniques based on inventory data from western Amazonia. Conservation Biology. 18(3): 799-811. URL: https://www.jstor. org/stable/3589090?seq $=1$

Holdridge LR. 1967. Life Zone Ecology. San José, Costa Rica: Tropical Science Center.

Holdridge LR. 1987. Ecología basada en zonas de vida. San José, Costa Rica: IICA.

Karremans AP, Albertazzi FJ, Bakker FT, Eurlings MCM, Pridgeon A, Pupulin F, Gravendeel B. 2016. Phyloge- 
netic reassessment of Specklinia and its allied genera in the Pleurothallidinae (Orchidaceae). Phytotaxa. 272: 1-36. URL: https://www.biotaxa.org/Phytotaxa/ article/view/phytotaxa.272.1.1

Kraenzlin FWL. 1925. New species of Masdevallia and allied genera. Bull Misc Inform Kew. 3: 116.

Lindley J. 1830. The genera and species of orchidaceous plants 8. London: J. Ridgway.

Luer CA. 1986. Icones Pleurothallidinarum III. Systematics of Pleurothallis (Orchidaceae). Monogr Syst Bot Missouri Bot. 20: 1-89.

Luer CA. 2003. Pleurothallis. In: B.E. Hammel, M.H. Grayum, C. Herrera, N. Zamora, editors. Manual de Plantas de Costa Rica. Vol. III. Monogr Syst Bot Missouri Bot. 95; p. 386-452.

Luer CA. 2004. Icones Pleurothallidinarum XXVI. Systematics of Pleurothallis subgenus Acianthera (Orchidaceae): a second century of new species of Stelis, Epibator, Ophidion, Zootrophion. Monogr Syst Bot Missouri Bot. 95: 1-258.

Luer CA. 2006. Icones Pleurothallidinarum XXVIII. A reconsideration of Masdevallia. Systematics of Specklinia and vegetatively similar taxa (Orchidaceae). Monogr Syst Bot Missouri Bot. 105: 1-94.

Mora C, Tittensor DP, Adl S, Simpson AGB, Worm B. 2011. How Many Species Are There on Earth and in the Ocean? PLoS Biol. 9(8): e1001127. URL: https:// journals.plos.org/plosbiology/article?id=10.1371/ journal.pbio.1001127

Ossenbach C, Pupulin F, Dressler RL. 2007. Orquídeas del Istmo Centroamericano catálogo y estado de conservación. Orchids of the Central American Isthmus. San José, Costa Rica: Editorial 25 de Mayo.

Pérez-Escobar OA, Chomicki G, Condamine FL, Karremans AP, Bogarín D, NJ Matzke, Silvestro D, Antonelli A. 2017. Recent origin and rapid speciation of Neotropical orchids in the world's richest plant biodiversity hotspot. New Phytologist. 215(2): 891-905. URL: https://nph.onlinelibrary.wiley.com/doi/full/10.1111/ nph.14629

Pessoa E, De Barros F, Alves M. 2014. Specklinia integripetala and S. ianthina spp. nov. (Orchidaceae: Pleurothallidinae) from northeastern Brazil. Nord J Bot. 32: 129-132. URL: https://onlinelibrary.wiley.com/ doi/abs/10.1111/j.1756-1051.2013.00183.x

Pridgeon AM, Solano R, Chase MW. 2001. Phylogenetic relationships in Pleurothallidinae (Orchidaceae): combined evidence from nuclear and plastid DNA sequences. American Journal of Botany. 88(12): 2286-2308. URL: https://pubmed.ncbi.nlm.nih.gov/21669661/

Pupulin F. 2001. Extending the range - A new Dracula from Costa Rica. Orchids. 70(6): 564-567.
Pupulin F. 2003. Tapantí - Orquídeas - Orchids. Cartago, Costa Rica: Jardín Botánico Lankester, Universidad de Costa Rica.

Pupulin F, Bogarín D, Jiménez D. 2009. New species and records in Mesoamerican Lepanthes. Orch Dig. 73: 136-145.

Pupulin F, Bogarín D. 2012. Lepanthes novae tapantiensis. Orch Dig. 76(1): 20-29.

Sánchez J. 2002. Aves del Parque Nacional Tapantí / Birds of Tapantí National Park. Heredia, Costa Rica: Ed. INBIO.

Schlechter FRR. 1923. Beiträge zur Orchideenkunde von Zentralamerika. II: Additamenta ad Orchideologiam Costaricensem. Repert Spec Nov Regni Veg. Beih 19: $22-23$. 